\title{
SENSITIFITAS DAN SPESIFISITAS RASIO LINGKAR PINGGANG-PANGGUL TERHADAP INDEKS MASSA TUBUH DALAM MENENTUKAN OBESITAS
}

\author{
Septi Nur Rachmawati \\ Program Studi Magister IImu Gizi, Fakultas Kedokteran, Universitas Diponegoro \\ Jl. dr. Suetomo No. 18 Semarang \\ Email : nura2737@gmail.com
}

\begin{abstract}
The most common indicator for detecting obesity is Body Mass Index (BMI). Besides BMI, the other indicator that is considered sensitive in detecting obesity is waist-to-hip ratio. How big the ability of this indicator in determining obesity truly need further testing. This study aims to test the sensitivity and specificity of waist-to-hip ratio in detecting obesity compared to BMI in women of childbearing age. This study is obsevational study with cross-sectional design. The sample was 100 women of childbearing age, 19-49 years old. The sensitivity and specificity tests were performed using Receiver Operator Characteristic (ROC) Curve. Cut-off to determine obesity is $>27 \mathrm{~kg} / \mathrm{m} 2$ calculated with $B M I$ and $>0.85$ calculated with waist-hip-ratio. Sensitivity value of waist-to-hip ratio is $74 \%$ (good enough) and the specificity value is $51 \%$ (less good). Based on ROC curve, Area Under Curve of waist-to-hip is 0,65 (poor). Waist-to-hip ratio has a poor ability to detect obesity in women of childbearing age. It is recommended to use other indicators to detect obesity in women of childbearing age.
\end{abstract}

Keywords : BMI, obesity, sensitivity, spesificity, waist-hip ratio

Abstrak : Indikator yang sering digunakan dalam menentukan obesitas adalah Indeks Massa Tubuh (IMT). Selain IMT, indikator lain yang dianggap sensitif dalam mendeteksi obesitas adalah rasio lingkar pinggang-panggung (RLPP). Seberapa besar kemampuan suatu indikator dalam menentukan yang benar-benar gemuk perlu dilakukan pengujian lebih lanjut.Penelitian ini bertujuan untuk menguji sensitifitas dan spesifisitas RLPP dalam mendeteksi obesitas dibandingkan dengan IMT pada wanita usia subur. Penelitian ini merupakan penelitian observasional dengan desain cross-sectional. Sampel penelitian adalah 100 orang wanita usia subur berusia 19-49 tahun. Uji sensitifitas dan spesifisitas dilakukan menggunakan Receiver Operator Characteristic (ROC) Curve.Cut-off untuk menentukan obesitas adalah $>27 \mathrm{~kg} / \mathrm{m}^{2}$ dengan perhitungan IMT dan $>0,85$ dengan perhitungan RLPP. RLPP mempunyai nilai sensitifitas $74 \%$ (cukup baik) dan spesifisitas $51 \%$ (kurang baik). Berdasarkan kurva ROC, Area Under Curve RLPP adalah 0,65 (jelek). RLPP memiliki kemampuan yang kurang baik dalam mendeteksi obesitas pada wanita usia subur. Disarankan untuk menggunakan indikator lain untuk mendeteksi obesitas pada wanita usia subur.

Kata Kunci : IMT, obesitas, sensitifitas, spesifisitas, RLPP

\section{PENDAHULUAN}

Kegemukan merupakan kondisi adanya timbunan lemak di dalam tubuh secara berlebih (1). Dari tahun ke tahun, prevalensi obesitas terus meningkat. Hal ini terjadi seiring meningkatnya taraf kesejahteraan masyarakat. $\mathrm{Di}$ Indonesia, prevalensi obesitas pada perempuan dewasa (>18 tahun) sebesar $32,9 \%$ pada tahun 2013. Angka ini naik $18,1 \%$ dari tahun $2007(13,9 \%)$ dan $17,5 \%$ dari tahun $2010(15,5 \%)(2)$.

Penilaian status gizi sebagai langkah awal dalam pendeteksian obesitas. Antropometri merupakan salah satu indikator yang dalam menentukan status gizi. Diberbagai negara, pengukuran IMT dianggap indikator terbaik untuk menentukan status gizi orang dewasa karena menggunakan 2 indikator pertumbuhan, yaitu berat badan dan tinggi badan (3). Hasil pengukuran IMT dapat dikategorikan menjadi gizi kurang, gizi normal, dan gizi lebih. Dikatakan obesitas jika memiliki IMT >27 (4). Indikator lain yang cukup dianggap sensitif untuk menentukan obesitas adalah lingkar pinggang dan rasio antara lingkar pinggang dan lingkar panggul (RLPP) (5). RLPP juga telah banyak digunakan pada wanita sebagai prediktor gangguan metabolik (6). Berdasarkan RLPP, wanita dikatakan obesitas jika nilainya $>0,85$ (7). Penelitian ini akan membandingkan RLPP dengan IMT sebagai gold standart. Penelitian ini bertujuan untuk menguji sensitifitas dan spesifisitas RLPP dalam mendeteksi obesitas dibandingkan dengan IMT pada wanita usia subur.

\section{METODE PENELITIAN}

Penelitian ini adalah penelitian observasional dengan desain cross sectional. 
Penelitian ini menggunakan data sekunder dari hasil Pre Dietetic Internship Community Universitas Brawijaya pada 5 Kecamatan (Ardimulyo, Jabung, Tajinan, Bululawang, dan Pujon) Kabupaten Malang tahun 2016. Sampel penelitian adalah wanita usia subur usia 19-49 tahun sebanyak 100 orang dengan kriteria inklusi tidak hamil dan tidak ada gangguan anatomis seperti bungkuk atau patah tulang. Variabel yang diamati meliputi berat badan, tinggi badan, IMT, lingkar pinggang, lingkar panggul dan RLPP.

Analisis validitas RLPP untuk mendeteksi obesitas dilakukan berdasarkan nilai sensitivitas dan spesifisitas terhadap IMT yang dijadikan gold standard. Sensitifitas adalah kemampuan RLPP dalam mendeteksi responden yang gemuk dengan benar, sedangkan spesifisitas merupakan kemampuan RLPP untuk mendeteksi responden yang tidak mengalami kegemukan (8). Hubungan analisis sensitivitas dan spesifisitas pengukuran akan ditampilkan dalam bentuk kurva Receiver Operating
Characteristic (ROC) dan Area Under Curve (AUS). Kurva ROC akan menampilkan kepekaan dan FPR pada semua tingkat kemungkinan ambang batas (9). Sedangkan AUC merupakan ukuran keseluruhan kinerja tes diagnostik yang diinterpretasikan sebagai rata-rata nilai sensitivitas untuk semua kemungkinan nilai spesifisitas (10). Nilai AUC terentang antara 0 dan 1 karena sumbu $x$ dan y mempunyai nilai mulai dari 0 sampai 1 . Jika nilai AUC mendekati 1, kinerja keseluruhan tes diagnostik semakin baik dan tes dengan nilai $A \cup C=1$ berarti kinerja sangat akurat (9). Nilai $A \cup C=1,0$ sempurna; antara $0,9-0,99$ sangat baik; 0,8-0,89 baik; 0,7-0,9 biasa; dan 0-510,69 jelek (2).

Analisa statistik menggunakan SPSS versi 16.0 Uji normalitas menggunakan Kolmogrov Smirnov test. Jika data terdistribusi normal, maka data akan disajikan dalam bentuk mean \pm standard deviasi (Mean \pm SD). Jika data tidak terdistribusi normal, maka akan disajikan dalam bentuk median (Interquartile Range).

HASIL

Hasil uji normalitas data menunjukkan bahwa data tinggi badan, lingkar pinggang, dan lingkar panggul terdistribusi normal. Sedangkan data berat badan, IMT, dan RLPP tidak terdistribusi normal. Hasil pengukuran antropometri disajikan pada Tabel 1. Rata-rata tinggi badan adalah 1,5 m dan berta badan $58,6 \mathrm{~kg}$. Rata-rata lingkar pinggang $84,66 \mathrm{~cm}$ dan lingkar panggul $95,56 \mathrm{~cm}$. Berdasarkan ratarata IMT, dapat diketahui jika rata-rata responden termasuk overweight $\left(>25 \mathrm{~kg} / \mathrm{m}^{2}\right)$. Sedangkan dari rata-rata RLPP, sebagian besar termasuk kategori obesitas $(>0,85)$.

Tabel 1. Hasil Pengukuran Antropometri

\begin{tabular}{ll}
\hline Parameter & Mean/Median \\
\hline $\mathrm{BB}(\mathrm{kg})^{*}$ & $58,28(34 ; 87,4)$ \\
\hline $\mathrm{TB}(\mathrm{cm})$ & $1,50 \pm 5,163$ \\
\hline $\mathrm{IMT}\left(\mathrm{kg} / \mathrm{m}^{2}\right)^{*}$ & $25,29(16,4 ; 40,12)$ \\
\hline Lingkar pinggang $(\mathrm{cm})$ & $84,66 \pm 1,197$ \\
\hline Lingkar panggung $(\mathrm{cm})$ & $95,56 \pm 1,104$ \\
\hline RLPP $^{*}$ & $0,86(0,58 ; 1,39)$ \\
\hline
\end{tabular}

Sensitifitas dan spesifisitas

Jumlah responden yang termasuk obesitas dan bukan obesitas berdasarkan IMT dan RLPP disajikan pada Tabel 2.

Tabel 2. Kejadian Obesitas Berdasarkan IMT dan RLPP IMT

\begin{tabular}{llccc}
\hline & IMT & & \\
\hline RLPP & Obesitas n (\%) & $\begin{array}{l}\text { Non-obes } \\
\text { n (\%) }\end{array}$ & $\begin{array}{l}\text { Total } \\
\text { n (\%) }\end{array}$ \\
\hline & Obesitas & $23(23 \%)$ & $34(34 \%)$ & $57(57 \%)$ \\
\hline Total & Non-obes & $8(8 \%)$ & $35(35 \%)$ & $43(43 \%)$ \\
\hline
\end{tabular}

Suatu alat ukur dikatakan cukup valid dan reliabel untuk digunakan sebagai indikator jika alat tersebut memiliki keseimbangan sensitivitas (Se) dan spesifisitas (Sp) yang terbaik dan paling sedikit 0,8 (11). Hasil perhitungan Se dan Sp pada RLPP secara berturu-turut adalah 0,74 dan 0,51. 


\section{Kurva ROC}

ROC Curve

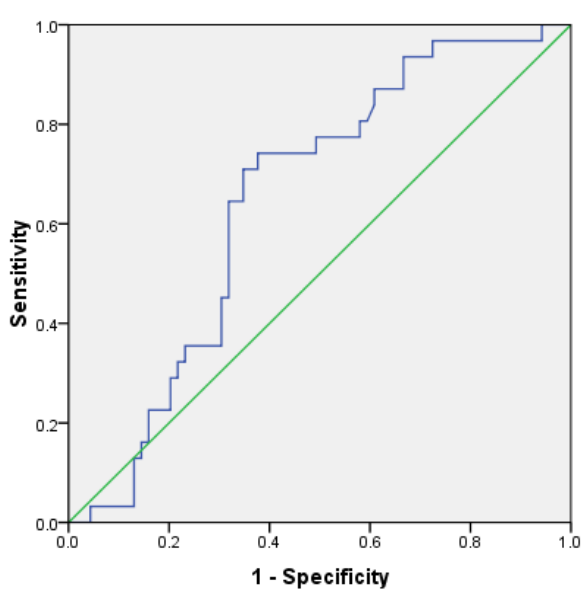

Gambar 1. Kurva ROC untuk RLPP $(A \cup C$ 0,65) dibandingkan dengan IMT

Gambar 1. menunjukkan perbandingan kurva ROC antara RLPP dengan IMT. Pada kurva tersebut menunjukkan AUC sebesar 0,65 yang termasuk dalam kategori jelek. Analisis ROC bertujuan memaksimalkan nilai yang menunjukkan bahwa baik responden dengan obesitas maupun tidak obesitas dapat diklasifikasikan dengan benar. Pada Tabel 3. menyajikan kombinasi sensitifitas dan spesifisitas RLPP berdasarkan kurva ROC. Berdasarkan kurva ROC, tidak ada satupun kombinasi spesifisitas dan sensitifitas $>0,8$. Cut-off RLPP untuk menentukan obesitas berdasarkan WHO adalah 0,85 . Pada rentang cut-off 0,85 , RLPP memiliki sensifitas yang cukup baik $(0,7)$, tapi spesifisitasnya kurang $(0,5)$.

Tabel 3. Area Under the ROC Curve (AUC), Sensitifitas, Spesifisitas dari RLPP

\begin{tabular}{cccc}
\hline Cut-Off & Sensitivitas & 1-Spesifisitas & Spesifisitas \\
\hline 0,84 & 0,77 & 0,57 & 0,43 \\
\hline 0,84 & 0,77 & 0,55 & 0,45 \\
\hline 0,84 & 0,77 & 0,54 & 0,46 \\
\hline $\mathbf{0 , 8 5}$ & $\mathbf{0 , 7 7}$ & $\mathbf{0 , 5 2}$ & $\mathbf{0 , 4 8}$ \\
\hline $\mathbf{0 , 8 5}$ & $\mathbf{0 , 7 7}$ & $\mathbf{0 , 5 1}$ & $\mathbf{0 , 4 9}$ \\
\hline $\mathbf{0 , 8 5}$ & $\mathbf{0 , 7 7}$ & $\mathbf{0 , 4 9}$ & $\mathbf{0 , 5 1}$ \\
\hline $\mathbf{0 , 8 5}$ & $\mathbf{0 , 7 4}$ & $\mathbf{0 , 4 9}$ & $\mathbf{0 , 5 1}$ \\
\hline $\mathbf{0 , 8 5}$ & $\mathbf{0 , 7 4}$ & $\mathbf{0 , 4 8}$ & $\mathbf{0 , 5 2}$ \\
\hline $\mathbf{0 , 8 5}$ & $\mathbf{0 , 7 4}$ & $\mathbf{0 , 4 6}$ & $\mathbf{0 , 5 4}$ \\
\hline 0,86 & 0,74 & 0,45 & 0,55 \\
\hline 0,86 & 0,74 & 0,43 & 0,57 \\
\hline 0,86 & 0,74 & 0,42 & 0,58 \\
\hline 0,86 & 0,74 & 0,41 & 0,59 \\
\hline 0,86 & 0,74 & 0,39 & 0,61 \\
\hline 0,86 & 0,74 & 0,38 & 0,62 \\
\hline 0,86 & 0,71 & 0,38 & 0,62 \\
\hline 0,87 & 0,71 & 0,36 & 0,64 \\
\hline 0,87 & 0,71 & 0,35 & 0,65 \\
\hline 0,87 & 0,68 & 0,35 & 0,65 \\
\hline 0,87 & 0,65 & 0,35 & 0,65 \\
\hline 0,87 & 0,65 & 0,33 & 0,67 \\
\hline 0,87 & 0,65 & 0,32 & 0,68 \\
\hline 0,87 & 0,61 & 0,32 & 0,68 \\
\hline 0,88 & 0,58 & 0,32 & 0,68 \\
\hline
\end{tabular}




\section{PEMBAHASAN}

Berdasarkan nilai AUC, RLPP termasuk kategori jelek dalam mengklasifikasikan obesitas. Bahkan penggunaan cut-off 0,85 sebagaimana yang direkomendasikan WHO mempunyai kombinasi sensitifitas dan spesifisitas yang tidak mencapai 0,7. Penelitian ini sesuai dengan penelitian pada responden dewasa Kaukasia yang menunjukkan bahwa RLPP bukan indikator yang valid dalam memprediksi lemak tubuh. Hal ini disebabkan pengukuran RLPP dipengaruhi oleh struktur tulang pelvis sehingga perhitungan distribusi lemak dan jaringan tanpa lemak tidak akurat (5). Di Nigeria, sebuah studi dengan subyek wanita dewasa menyatakan bahwa sensitifitas dan

\section{DAFTAR PUSTAKA}

Ho PS, Mo GJ, Jo CH. Receiver operating characteristic (ROC) curve:practical review for radiologists. Korean Journal Radiology. 2004; I 5:11-18.

Kalsum U, Sutrisna B, Djuwita R, Achadi EL, Jahari $A B$. A New Alternative Indicator for Chronic Energy Deficiency in Women of Childbearing Age in Indonesia. Health Science Indones, 2014, Vol 5, No 2.

Kemenkes RI. 2013. Riset Kesehatan Dasar.

Ketel IJG, Volman MNM, Seidell JC, Stehouwer CDA, Twisk JW, Lambalk CB. Superiority of Skinfold Measurements and Waist over Waistto-Hip Ratio for Determination of Body Fat Distribution in a Population-Based Cohort of Caucasian Dutch Adults. European Journal of Endocrinology. 2007; 156(6): 655-651.

Metz CE. Basic principles of ROC analysis. Seminars in NuclearMedicine. 1978; 8: 283-98.

Odenigbo UM, Odenigbo UC, Oguejiofor OC, Adogu, POU. Relationship of Waist Circumference, Waist Hip Ratio and Body Mass Index as Predictors of Obesity in Adult Nigerians. Pakistan Journal of Nutrition. 2011; 10(1): 15. spesifisitas RLPP untuk mendeteksi obesitas lebih rendah dibanding indikator lain seperti lingkar pinggang (12). Penelitian di Indonesia juga menunjukkan hal serupa. RLPP merupakan indikator yang paling rendah dalam mendeteksi obesitas pada wanita usia subur jika dibandingkan dengan IMT dan lingkar pinggang (2).

\section{KESIMPULAN DAN SARAN}

RLPP mempunyai kemampuan yang kurang baik dalam mendeteksi obesitas pada wanita usia subur. Disarankan menggunakan indikator lain selain RLPP yang mempunyai sensitifitas dan spesifisitas lebih baik untuk menentukan obesitas pada wanita usia subur

Parikh R, Mathai A, Parikh S, Sekhar GC, Thomas R. Understanding and Using Sensitivity, Specificity, and Predictive Values. Indian J Ophthalmol. 2008; 56(1): 45-50.

Permenkes RI No. 41 Tahun 2014. Pedoman Gizi Seimbang.

Stanković V, Stojanović S, Vasiljević N. Evaluation of Anthropometric Indices for Metabolic Syndrome and their Association with Metabolic Risk Factors among Healthy Individuals in New Belgrade. Scientific Journal of the Faculty of Medicine in Nis. 2013; 30(1): 21-30.

Triwinarto A, Muljati S, Jahari AB. Cut-off Point Indeks Massa Tubuh (IMT) dan Lingkar Perut Sebagai Indikator Risiko Diabetes dan Hipertensi pada Orang Dewasa di Indonesia. Panel Gizi Makan, 2012, 35(2), 119-135.

WHO. 2011. Waist Circumference and Waist-Hip Ratio : report of a WHO Expert Consultation.

Wirawan NN. Sensitifitas dan Spesifisitas IMT dan Lingkar Pinggang-Panggul dalam Mengklasifikasikan Kegemukan pada Wanita. Indonesian Journal of Human Nutrition, 2016;3(1):49-59. 